\title{
Characterization of Pamelo Leaves (Citrus maxima (Burm) Merr) Aceh, Indonesia
}

\author{
Ismadi Yunus*, Intan Yatima Putri, Hafifah \\ Department of Agroecotechnology, Universitas Malikussaleh, Kampus Cot Teungku Nie Reuleut, Muara Batu, Aceh Utara, Indonesia, 24355. \\ *Corresponding author: ismadi@unimalac.id
}

\section{ARTICLE HISTORY}

Received: 15 July 2018

Revised: 18 July 2018

Accepted: 12 September 2018

\section{KEYWORDS}

Lamina

Leaf division

Leaf blade

Leaf color

Petiole

\begin{abstract}
Pamelo (Citrus maxima (Burm.) Merr) is one type of orange that is prospectively cultivated in Indonesia. Pamelo in Indonesia is very diverse, as the skin of the fruit is green to red, some are with seed and seedless. Pamelo plants have diverse leaves, both in shape, size, lamina and thickness. The various leaf shapes between plants which show below the genetic resources of pamelo plants are numerous and varied. Information about pamelo aceh plants, especially about the character of leaves is still very limited. This information can be used to determine the characteristics of pamelo aceh so that later it will be very useful in classifying and grouping plants. The purpose of this study was to determine the character of the Pamelo Giri Matang leaf in Aceh, Indonesia. The study aims to see the level of diversity of pamelo in the village of Pante Lhong. The study was conducted in the village of Pante Lhong, Peusangan District, Bireuen, District, Aceh, Indonesia and at the Laboratory of Agroecotechnology, Faculty of Agriculture, Universitas Malikussaleh, from September to November 2017. The sample plants used were 15, aged between 10 and 25 years. The research was conducted using descriptive method with sampling by purposive sampling method. Observations were carried out quantitatively and qualitatively based on Descriptors for Citrus (PGRI). The results showed that Pamelo Giri Matang Aceh Indonesia was an evergreen plant with an intensity of green to dark leaf color. The average leaf lamina has a length of $14.62 \mathrm{~cm}$ and a width of $7.04 \mathrm{~cm}$ with an average area of $59.74 \mathrm{~cm}^{2}$. The most

commonly found leaf wings are obovate.
\end{abstract}

This is an open access article under the CC-BY-SA license.

\section{INTRODUCTION}

Pamelo (Citrus maxima (Burm.) Merr) is a type of orange that is prospectively cultivated in Indonesia, including Aceh. Pamelo in Indonesia is very diverse, as the skin of the fruit is green to red, with seed and seedless (Susanto et al., 2011; Rahayu, 2012). Pamelo also has a variety of flavors, some are sweet but some are bitter, the skin is easy to peel and some are not easily peeled.

Likewise, with leaves, pamelo plants have a variety of leaves, both shape, size, lamina, and thickness (IPGRI, 1999). The diverse leaf shape between plants shows that the genetic resources of pamelo plants are numerous and varied. Pamelo leaves are ovoid to oval (Susanto, Rahayu, Tyas, 2013; Rai et al, 2015).

Information about pamelo aceh plants, especially about the character of leaves is still very limited. This information can be used to determine the characteristics of pamelo aceh so that later it will be very useful in classifying and grouping plants. The purpose of this study was to determine the character of the Pamelo Giri Matang leaf in Aceh, Indonesia.

\section{MATERIALS AND METHODS}

The study was conducted from September to November 2017. The sample plants were from Pante Lhong Village, Peusangan District, Bireuen District, Aceh, Indonesia. The analysis was conducted at the Laboratory of Agroecotechnology, Faculty of Agriculture, Universitas Malikussaleh. The sample plants used were 15, aged between 10 and 25 years. The tools used are knives, altimeter guard, meters, analytical scales, and cameras.

The research was conducted using descriptive method with sampling by purposive sampling method. Observations are carried out quantitatively and qualitatively based on Descriptors for Citrus (PGRI, 1999).

\section{RESULTS AND DISCUSSION}

\subsection{Leaf Character}

Vegetative life cycle of the leaves of the pamelo Giri Matang Aceh plant is an evergreen with a simple leaf division. 
Pamelo plants never drop their leaves together in certain seasons, but leaves that fall because they are old. The intensity of green color of laef blades is two, namely medium and dark and almost a draw between the two types. Leaf color variegation is not found on the leaves of the pamelo Giri Matang plant. Leaf lamina are brevipetiolate in which petiole is shorter than leaf lamina (Table 1).

Table 1. Leaf Characteristics of Pamelo Giri Matang Aceh, Indonesia

\begin{tabular}{|c|c|c|c|c|c|}
\hline Aksesi & Vegetative life cycle & Leaf devision & $\begin{array}{l}\text { Intensity of green } \\
\text { color of laef blade }\end{array}$ & Leaf color variegation & Leaf lamina attachment \\
\hline Giri Matang PLTD-01 & Evergreen & simple & Dark & Absent & Brevipetiolate \\
\hline Giri Matang PLTD-02 & Evergreen & simple & Dark & Absent & Brevipetiolate \\
\hline Giri Matang PLTD-03 & Evergreen & simple & Medium (green) & Absent & Brevipetiolate \\
\hline Giri Matang PLTD-04 & Evergreen & simple & Medium (green) & Absent & Brevipetiolate \\
\hline Giri Matang PLTS-1 & Evergreen & simple & Medium (green) & Absent & Brevipetiolate \\
\hline Giri Matang PLTS-02 & Evergreen & simple & Dark & Absent & Brevipetiolate \\
\hline Giri Matang PLTS-03 & Evergreen & simple & Dark & Absent & Brevipetiolate \\
\hline Giri Matang PLTS-04 & Evergreen & simple & Dark & Absent & Brevipetiolate \\
\hline Giri Matang PLDP-01 & Evergreen & simple & Medium (green) & Absent & Brevipetiolate \\
\hline Giri Matang PLDP-02 & Evergreen & simple & Dark & Absent & Brevipetiolate \\
\hline Giri Matang PLDP-03 & Evergreen & simple & Medium (green) & Absent & Brevipetiolate \\
\hline Giri Matang PLDP-04 & Evergreen & simple & Dark & Absent & Brevipetiolate \\
\hline Giri Matang PLIG-01 & Evergreen & simple & Medium (green) & Absent & Brevipetiolate \\
\hline Giri Matang PLIG-02 & Evergreen & simple & Dark & Absent & Brevipetiolate \\
\hline Giri Matang PLIG-03 & Evergreen & simple & Medium (green) & Absent & Brevipetiolate \\
\hline Dominant & Evergreen & simple & Dark & Absent & Brevipetiolate \\
\hline
\end{tabular}

\section{2}

\section{Character of Leaf Lamina}

Pamelo Giri Matang leaves have an average length of 14.62 $\mathrm{cm}$ lamina, where the shortest is $13.33 \mathrm{~cm}$ long and 16.16 $\mathrm{cm}$ longest. The width of the lamina leaves between 6.48-7.99 $\mathrm{cm}$ with an average width of $7.04 \mathrm{~cm}$. The average area of lamina is $59.74 \mathrm{~cm}^{2}$ with a ratio of $2.11 \mathrm{~cm}$. Pamelo Giri Matang leaves are between 0.27-0.36 mm with an average thickness of $0.34 \mathrm{~mm}$ (Table 2).

The length of pamelo leaves can reach $15-20 \mathrm{~cm}$ with a width of 8.5-12 cm (Rai et al, 2015). Leaf area affects photosynthesis results and reflects the area of photosynthesis. The wider the leaf, the easier it is to get sunlight for photosynthesis.

Leaf lamina shape found in the pamelo Giri Matang there are three types namely elliptic, ovate and obovate with the most dominant elliptic form. Leaf lamina margins are found in two forms, namely crenate and entire. Pamelo Giri Matang leaf apex leaves are almost all menirus shaped (Table 3). Various forms of lamina of pamelo Giri Matang leaves are shown in Figures 1, 2 and 3.

Table 2. Character of Leaf Lamina Pamelo Giri Matang Aceh, Indonesia

\begin{tabular}{|c|c|c|c|c|c|c|c|}
\hline Aksesi & $\begin{array}{l}\text { Leaf lamina } \\
\text { lenght }\end{array}$ & $\begin{array}{l}\text { Leaf lamina } \\
\text { Width }\end{array}$ & $\begin{array}{c}\text { Ratio Leaf lamina } \\
\text { length/Width }\end{array}$ & $\begin{array}{l}\text { broad lamina } \\
\text { leaves }\end{array}$ & $\begin{array}{l}\text { Leaf } \\
\text { thickness }\end{array}$ & $\begin{array}{l}\text { Leaf lamina } \\
\text { shape }\end{array}$ & $\begin{array}{l}\text { Leaf lamina } \\
\text { margin }\end{array}$ \\
\hline & 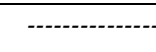 & $--\mathrm{cm}$--- & (n) & $--\mathrm{cm}^{2}--$ & $--m m--$ & & \\
\hline Giri Matang PLTD-01 & 14.84 & 6.99 & 2.12 & 59.28 & 0.35 & Eliptic & crenate \\
\hline Giri Matang PLTD-02 & 13.33 & 6.52 & 2.04 & 50.47 & 0.38 & Eliptic & crenate \\
\hline Giri Matang PLTD-03 & 15.44 & 6.55 & 2.35 & 56.07 & 0.35 & Ovate & crenate \\
\hline Giri Matang PLTD-04 & 15.78 & 7.87 & 2.01 & 71.81 & 0.36 & Eliptic & crenate \\
\hline Giri Matang PLTS-01 & 13.93 & 6.67 & 2.10 & 52.98 & 0.27 & Eliptic & entire \\
\hline Giri Matang PLTS-02 & 16.15 & 7.95 & 2.32 & 73.03 & 0.36 & Eliptic & Entire \\
\hline Giri Matang PLTS-03 & 15.60 & 7.99 & 1.96 & 77.28 & 0.31 & Eliptic & crenate \\
\hline Giri Matang PLTS-04 & 14.26 & 7.15 & 2.00 & 59.52 & 0.31 & Eliptic & crenate \\
\hline Giri Matang PLDP-01 & 14.01 & 6.48 & 2.17 & 51.55 & 0.29 & Eliptic & crenate \\
\hline Giri Matang PLDP-02 & 14.45 & 6.70 & 2.19 & 54.88 & 0.33 & Ovate & entire \\
\hline Giri Matang PLDP-03 & 14.69 & 6.90 & 2.14 & 59.01 & 0.34 & Eliptic & entire \\
\hline Giri Matang PLDP-04 & 15.46 & 7.80 & 2.00 & 67.76 & 0.32 & Ovate & crenate \\
\hline Giri Matang PLIG-01 & 13.37 & 6.49 & 2.07 & 51.81 & 0.35 & Obovate & crenate \\
\hline Giri Matang PLIG-02 & 13.81 & 6.59 & 2.11 & 52.25 & 0.35 & Ovate & crenate \\
\hline Giri Matang PLIG-03 & 14.25 & 7.01 & 2.05 & 58.37 & 0.38 & Eliptic & crenate \\
\hline Average/Dominant & 14.62 & 7.04 & 2.11 & 59.74 & 0.34 & Eliptic & crenate \\
\hline
\end{tabular}



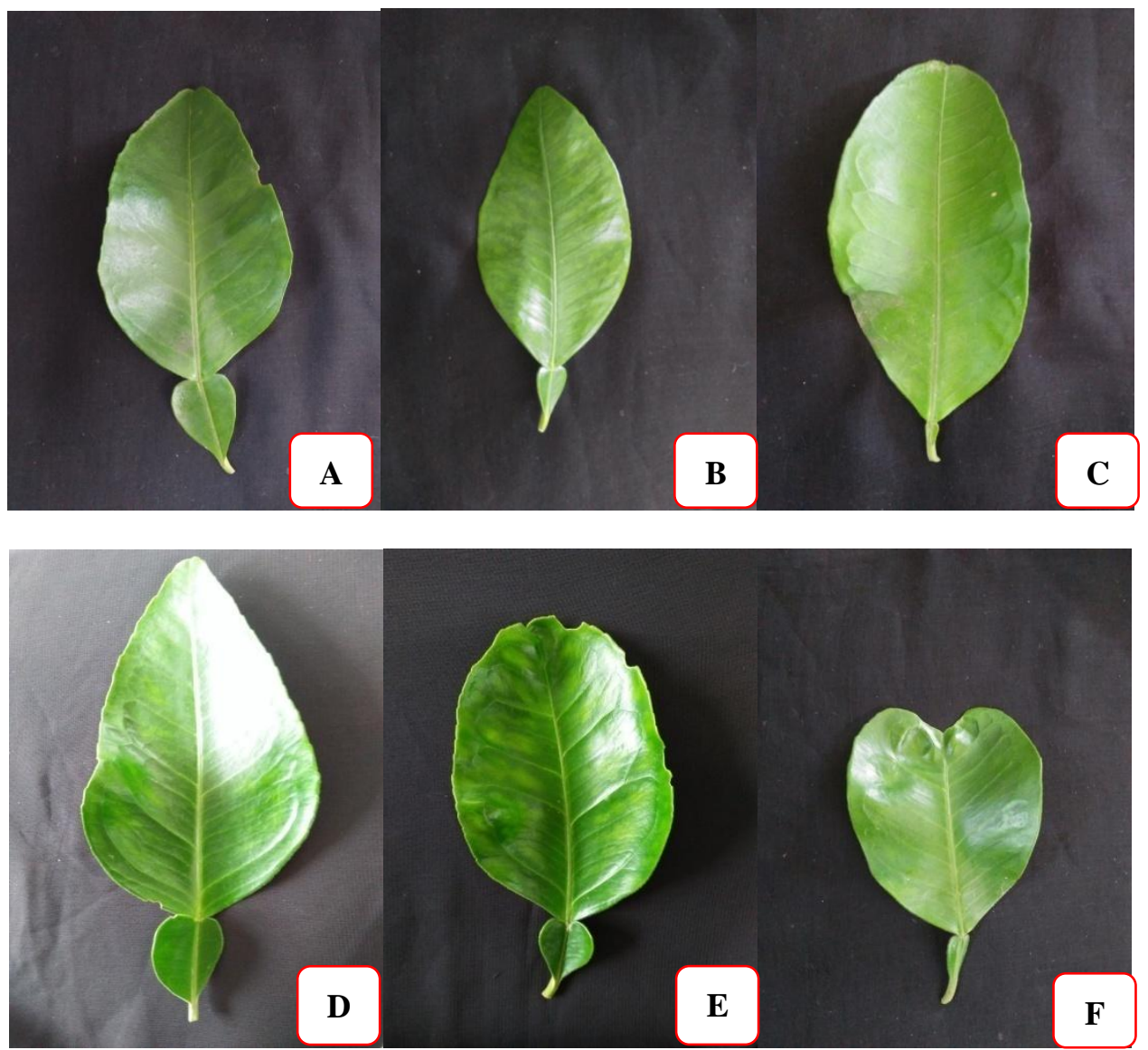

Figure 1. Character of Leaf Lamina Pamelo Giri Matang Aceh, Indonesia. Eliptic (A); ovate (B); Obovate(C); Lanceolate (D); Orbicular (E); Obcordata (F).

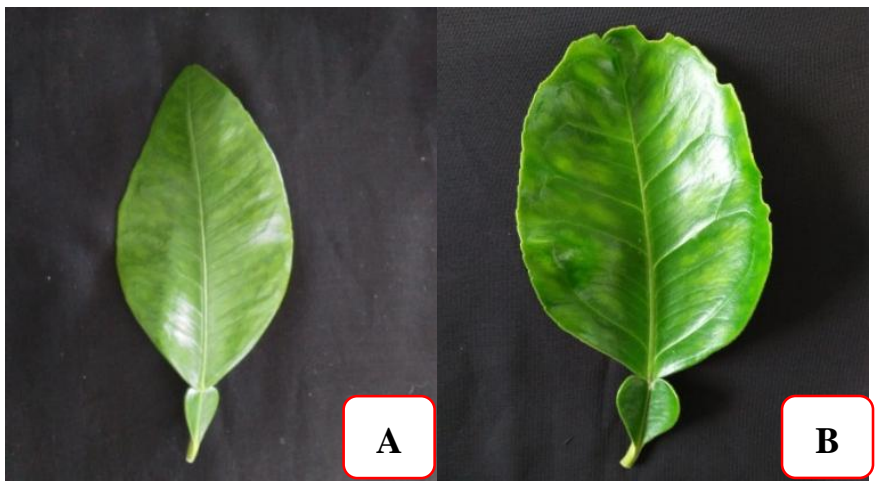

Figure 2. Character of Leaf Lamina Margin Pamelo Giri Matang Aceh, Indonesia.entire (A.); Crenate (B).

\subsection{Shape of the Petiole Leaf}

There are three basic forms of petiole wings, including obcordata, obdeltate, and obovate and the most common is obovate. However, many also found the obcordata and obdeltate leaf stalk wings (Table 4). Nambangan and Sri Nyonya type Pamelos which have an average wing shape obcordata (Hardiyanto et al, 2007). The wings of the pamelo petiole are of average medium size, but compared to other types of citrus, pamelo leaf wings are the broadest (Ortiz, 2002). The shape of the wing of the petiole leaf and the mid between the strands and the wing of the leaf can be seen as in Figure 3.
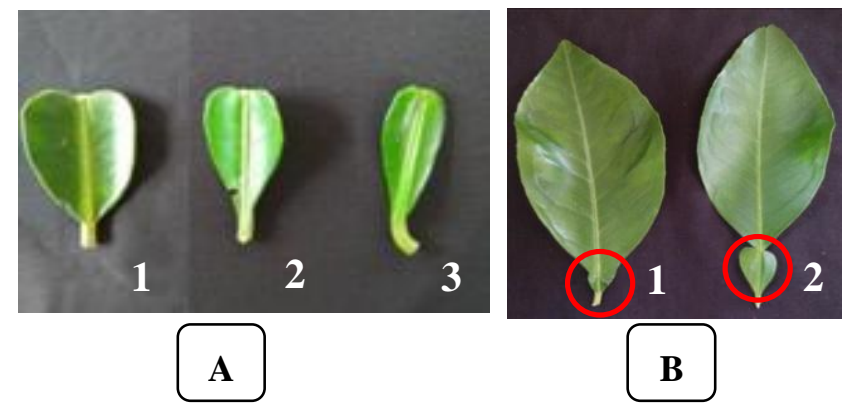

Figure 3. Character of Petiole Wing Shape Pamelo Giri Matang Aceh, Indonesia. A. 1.) obcordata, 2.) obdeltate; 3.) obovate); and B: Junction Between Petiole and a Lamina: 1.) fused; 2.) articulate 
Tabel 3. Character of Petiole Leaf Pamelo Giri Matang Aceh, Indonesia

\begin{tabular}{|c|c|c|c|c|}
\hline Aksesi & $\begin{array}{c}\text { Absence/presence of petiole } \\
\text { wings }\end{array}$ & Petiole wing width & Petiole wing shape & $\begin{array}{c}\text { Jungtion between petiole } \\
\text { and lamina }\end{array}$ \\
\hline Giri Matang PLTD-01 & present & Medium & Obovate & articulate \\
\hline Giri Matang PLTD-02 & present & Medium & Obovate & articulate \\
\hline Giri Matang PLTD-03 & present & Broad & Obovate & articulate \\
\hline Giri Matang PLTD-04 & present & Medium & Obcordata & articulate \\
\hline Giri Matang PLTS-01 & present & Medium & Obovate & articulate \\
\hline Giri Matang PLTS-02 & present & Medium & Obdeltate & articulate \\
\hline Giri Matang PLTS-03 & present & Narrow & Obovate & articulate \\
\hline Giri Matang PLTS-04 & present & Broad & Obdeltate & articulate \\
\hline Giri Matang PLDP-01 & present & Narrow & Obovate & articulate \\
\hline Giri Matang PLDP-02 & present & Medium & Obovate & articulate \\
\hline Giri Matang PLDP-03 & present & Medium & Obovate & articulate \\
\hline Giri Matang PLDP-04 & present & Medium & Obdeltate & articulate \\
\hline Giri Matang PLIG-01 & present & Narrow & Obovate & articulate \\
\hline Giri Matang PLIG-02 & present & Broad & Obdeltate & articulate \\
\hline Giri Matang PLIG-03 & present & Medium & Obcordata & articulate \\
\hline Dominant & present & Medium & Obovate & articulate \\
\hline
\end{tabular}

\section{CONCLUSION}

Pamelo Giri Matang Aceh Indonesia is an evergreen plant with an intensity of green to dark leaf color. The average leaf lamina has a length of $14.62 \mathrm{~cm}$ and a width of $7.04 \mathrm{~cm}$ with an average area of $59.74 \mathrm{~cm}^{2}$. The most commonly found leaf wings are obovate.

\section{REFERENCES}

Hardiyanto, E. Mujiarto, E. S. Sulasmi. 2007. Kekerabatan genetik beberapa spesies jeruk berdasarkan taksonometri. J. Hort 17: 203-206.

[IPGRI] International Plant Genetic Resources Institute. 1999. Descriptors for Citrus. International Board for Plant Genetic Resource, Rome.

Ortiz, J. M. 2002. Botany: Taxonomy, Morphology and Physiology of Fruits, Leaves and Flowers. Di dalam: Dugo, G. and Giacomo AD, editor. Citrus the genus Citrus. London and New York: Taylor and Francis.

Rahayu, A. 2012. Karakterisasi dan Evaluasi Aksesi Pamelo (Citrus maxima (Burm) Merr.) Berbiji dan Tidak Berbiji Asli Indonesia. [Dissertation]. Bogor Agricultural University. Bogor.

Rai, I. N., G. Wijana, P. Sudana, I. W. Wiratmaja. 2015. Jeruk Besar. Penelitian Prioritas Nasional Masterplan Percepatan Dan Perluasan Pembangunan Ekonomi Indonesia 2011-2025 (Penprinas Mei 2011-2025). Bali

Susanto, S., A. Rahayu, D. Sukma, I. S. Dewi. 2011.Karakter Morfologi dan Kimia 18 Kultivar Pamelo (Citrus maxima (Burm.) Merr.) Berbiji dan Tanpa Biji. Jurnal Ilmu Pertanian Indonesia. Vol 16 (1). Hal: 43-48.

Susanto, S., A. Rahayu, K. N. Tyas. 2013. Ragam Pamelo Indonesia. Faculty of Agriculture, Bogor Agricultural University. Bogor. 